\title{
Transforming the tobacco market: why the supply of cigarettes should be transferred from for-profit corporations to non-profit enterprises with a public health mandate
}

\author{
C Callard, D Thompson, N Collishaw
}

Tobacco Control 2005;14:278-283. doi: 10.1136/tc.2005.011353

Current tobacco control strategies seek primarily to decrease the demand for cigarettes through measures that encourage individuals to adopt healthier behaviours. These measures are impeded and undermined by tobacco corporations, whose profit drive compels them to seek to maintain and expand cigarette sales. Tobacco corporations seek to expand cigarette sales because they are for-profit business corporations and are obliged under law to maximise profits, even when this results in harm to others. It is not legally possible for a for-profit corporation to relinquish its responsibility to make profits or for it to temper this obligation with responsibilities to support health. Tobacco could be supplied through other non-profit enterprises. The elimination of profit driven behaviour from the supply of tobacco would enhance the ability of public health authorities to reduce tobacco use. Future tobacco control strategies can seek to transform the tobacco market from one occupied by for-profit corporations to one where tobacco is supplied by institutions that share a health mandate and will help to reduce smoking and smoking related disease and death.

$\mathrm{T}$ he tobacco control strategies promoted by the World Health Organization, ${ }^{1}$ recommended by the World Bank, ${ }^{2}$ and now codified in the Framework Convention on Tobacco Control $^{3}$ (FCTC) are principally aimed at reducing the demand for tobacco. These measures include high tobacco taxes, bans on cigarette promotions, requirements for warning labels, smoke-free public spaces and workplaces, public education, and programmes to support quitting. The primary intent of these measures is to modify the mindset and behaviour of smokers or potential smokers, which is why they are considered to be "demand-side" interventions.

Although "supply-side" interventions are commonplace in other public health strategies (for example, the control of drugs with harm potential such as marijuana, oxycodone, or penicillin), they have not generally found favour with those public health authorities seeking to reduce tobacco use. ${ }^{12}$ Among supply-side tobacco interventions currently or recently in use are banning the sale of tobacco products to young persons, tariffs to reduce imports, non-tariff trade restrictions like quotas or other restrictions on imports, smuggling controls, and agricultural programmes to assist tobacco farmers. Only two of these, smuggling controls and banning sales to minors, are mandated in the FCTC, which also encourages the promotion of economically viable alternatives for tobacco workers and growers. ${ }^{3}$

Some researchers have suggested new supply-side measures to expand current tobacco control strategies. Recently, Borland has proposed that tobacco marketing should be controlled by a public agency with a legislated mandate to provide cigarettes in ways that reduce harm. ${ }^{4}$ Other proposed strategies include tobacco prohibition, ${ }^{5}$ bans on commercial tobacco trade, ${ }^{6}$ and penalties for possession by young people. ${ }^{7}$ Harm reduction proposals based on using state power to increase the availability of non-tobacco or non-smoked forms of nicotine ${ }^{8}$ are also supply-side policy measures.

An alternate supply-side approach is proposed in this paper. This proposal is designed to address the problems caused by the supply of cigarettes being managed by business corporations which are designed, built, managed, governed, and mandated to maximise profits, and which are programmed to continue to maximise profits even when doing so may result in human harm. ${ }^{9}$ This structural problem, we suggest, cannot be overcome by merely "regulating" the tobacco market, even if such regulations include direct control of the distribution of cigarettes, as proposed by Borland. Regulations in their current form can require tobacco corporations to alter certain discrete behaviours, but they do not weaken or alter the profit seeking drive that compels corporations to find new ways to expand cigarette sales.

We suggest that the tobacco problem lies not only in the nature of the product and the activities of those who sell it. It also lies in the political choice to allow business corporations to supply cigarettes. Greater advances against tobacco caused disease and death can be made if we choose different types of enterprises to provide tobacco, and ensure they have a public health mandate.

\section{WHY BUSINESS CORPORATIONS ARE THE WRONG CHOICE TO SUPPLY TOBACCO}

In most parts of the world, the tobacco market is dominated by a few large multinational tobacco corporations ${ }^{10}$ whose actions have been described as unethical, immoral, and dishonest. ${ }^{11}$ The US Department of Justice recently described tobacco industry behaviour as "fraudulent and tortious", claiming that the industry conspired, among other things, to lie about the health risks of smoking, to make their products more attractive to children, to deceive smokers about so called light cigarettes, to increase the addictiveness of their products while denying that cigarettes were addictive, and to avoid making their cigarettes less harmful. ${ }^{12}$ The World Health Organization has documented how the industry uses its economic and political influence to oppose government controls on tobacco products and to maintain marketing freedoms and social acceptability. ${ }^{1}$ Identifying the industry's role in the tobacco pandemic through tobacco industry denormalisation is now part of many health strategies ${ }^{13}$

Abbreviations: CSR, corporate social responsibility; FCTC, Framework Convention on Tobacco Control; RMM, regulated market model; TPA, Tobacco Products Agency 
and expressed in initiatives like the Massachusetts "Get outraged" or the American Legacy Foundation "Truth" campaigns. ${ }^{14}$

If tobacco industry actions are characterised as wrong, immoral, or unethical, it naturally follows that the standard tools of rehabilitation and reform (shaming, punishment, and imposed codes of conduct) are the primary approaches governments take to modify industry behaviour. If, on the other hand, tobacco industry behaviour is understood to be entirely rational and rule driven, then different approaches may have a greater impact. Ordering tobacco companies to change the way they behave may not be as effective as reprogramming tobacco companies to change the way they think.

A corporation is a legal fiction. It has no independent, real existence. Although corporations share some of the legal rights of persons, it is not appropriate to think of them, metaphorically, as human. If we anthropomorphise corporations, then we imbue them with qualities they do not have (like compassion, remorse, or joy) and will expect them to include moral or emotional considerations into their decisions and actions. They do not have this capacity. The people who work in or hold shares in a corporation have human qualities, but the corporation itself does not, any more than a ship has the feelings of those who built, own or sail upon her. A more accurate metaphor for a corporation is a machine, a computer program, or a car. Cars cannot feel sorry for the people they hurt, and neither can corporations.

The corporation is a legal instrument created for the sole purpose of facilitating trade, and it is programmed to do one thing exclusively-make money. As an inanimate object, the corporation has no moral responsibility to do anything else, and is incapable of feeling guilt about this selfish tendency. Nor do its employees, managers, or directors have the legal right or ability to impose their own morals or feelings on the corporation. They cannot change the corporation's sole focus on profit, nor act contrary to the corporation's mandate. Corporate law holds that they would be subject to termination and potentially a lawsuit if they tried.

The modern corporation did not emerge from a grand plan, but evolved through a series of ad hoc particular decisions, often the result of lobbying or litigation by a single corporation. For most of their history, corporations had carefully defined purposes (like building a particular bridge or canal), and were not able to live beyond the project or work in other sectors. Only in the past century did corporations gain the rights and characteristics (including mobility, limited liability, perpetual existence, and the ability to own other corporations) that allowed them to become the dominant social institution of our time. The corporation has changed, and continues to change through the ad hoc decisions of legislatures, investors, and courts. ${ }^{15}$

Although particular corporate structures change, the rule that corporate directors must act only in the "best interests of shareholders" has remained firm. Courts have interpreted best interests to mean the maximisation of profits since shareholder's value (that is, the price of their shares) is adjusted by the stock market to reflect current and anticipated corporate profits. ${ }^{9} 1617$ This rule helps protect shareholders from the potentially adverse competing financial interests of managers and directors, but it also makes corporations unable to pursue other goals that might be socially beneficial. This rule has transformed corporations into machines for extracting wealth and funnelling that wealth to its shareholders, while externalising environmental and social costs onto others wherever possible. ${ }^{9}$

Corporations are the archetypical rational economic actor: they are programmed to make rational decisions, usually on the basis of a cost-benefit analysis. When considering actions that may harm others, corporations will translate the short term and long term (discounted) regulatory, liability, and corporate reputation risks of such actions, and rationally factor these costs into their overall cost-benefit analysis. For example, if it costs tobacco corporations more to refrain from smuggling than to risk being caught smuggling, they can be expected to make the rational decision to smuggle. In an application for a search warrant, Canadian police described how British American Tobacco's affiliate, Imperial Tobacco Canada, determined in 1993 that it would be profitable to support the market for smuggled cigarettes in Canada, and altered its business practices accordingly. ${ }^{18}$

There are many examples of corporations in sectors other than tobacco taking decisions that they know break laws and even cause death, in order to increase profits. ${ }^{9}$ A famous example of this behaviour was the 1971 decision by the Ford Motor Co not to fix a known tendency of the gas tanks on its Pinto model cars to explode on impact. The corporation calculated that it would cost $\$ 11$ per car to fix the problem, and made a further calculation of how much they would have to pay in damages for 180 people they estimated would die as a result. Because they estimated it would cost more to fix the cars than to pay legal damages for the deaths, injuries, and damage, they decided against fixing the cars until they were required to do so by law. ${ }^{19}$ This is not isolated behaviour, but rather the corporate norm; GM undertook the same costbenefit analysis, with much the same results, in respect of its Chevrolet Malibu. ${ }^{9}$ Multinational Monitor regularly compiles a list of similar corporate decisions to put profits before public interest. ${ }^{20}$ Laws are effective when they carry sufficient sanctions and likelihood of enforcement to tilt the costbenefit equation and make compliance the rational corporate decision.

The idea that for-profit corporations should take into account the interests of a wider range of stakeholderscurrently framed as "corporate social responsibility" (CSR)has been discussed and critiqued for decades. ${ }^{21}$ Although proponents of CSR suggest that the range of corporate "stakeholders" should include more than just the shareholders, few if any dispute the clear rule of corporate law that management is not permitted to favour the interests of other stakeholders at the expense of share value. ${ }^{16}$ Hirschhorn described how Altria deliberatively engaged in CSR activities to increase the value of its stock. ${ }^{22}$ As an analysis of CSR in The Economist recently put it, "Nothing obliges someone who believes that the tobacco industry is evil to work in that industry. But if someone accepts a salary to manage a tobacco business in the interests of others, he has an obligation to those owners. To flout that obligation is unethical." ${ }^{23}$

Tobacco corporations, like all business corporations, are not evil, and they are not good; they are incapable of any moral judgment or culpability. Like other rule driven systems, their behaviour is programmed and predictable. In striving to sell more cigarettes and recruit new smokers, they are doing exactly what they were created to do (sell cigarettes) and what they are required to do (maximise the value of the corporation for its owners by making cigarettes as profitably as possible). The rules of corporate law combined with the forces of the competitive for-profit marketplace compel them to try to increase tobacco use. Even if a given tobacco corporation were to remove itself or be removed from the tobacco market, other companies would seek to replace it as long as it was in their shareholders' interest to do so.

This analysis has clear implications for public health. Tobacco companies will not stop selling cigarettes as long as it is in the interests of their shareholders to do so. In trying to increase their profits and thus the value of their shares, the companies will seek to sell more cigarettes. To sell more 
cigarettes, they will continue to try to defeat, weaken, and violate tobacco control measures. Health regulators may develop more sophisticated and stringent tobacco control measures, but the companies will reply with more sophisticated and imaginative strategies to blunt their effect. The result will be lower rates of quitting and higher rates of new smokers, preventable disease, and premature death than would be the case if cigarettes were supplied by institutions whose mandate did not force them to try to sell more cigarettes and weaken public health initiatives.

Liberman describes the "perverse incentive" by which tobacco companies' pursuit of profits runs headlong into and bowls over both legal principles that companies exercise a duty of care and public health measures. The tobacco industry has no "right" to profit from actions that increase harm, he argues, and that it "can only do what the community allows it to do". ${ }^{24}$ Even more effective than the community increasing the scope and depth of the regulatory environment in which tobacco companies operate, we suggest, is to remove them from the tobacco market altogether.

\section{OTHER FORMS OF BUSINESS INSTITUTIONS CAN BE USED TO SUPPLY TOBACCO PRODUCTS}

There are business forms other than the for-profit business corporation available to societies who wish to allow tobacco to be manufactured and sold, but who also wish to remove the corporate behaviour that delays reductions in tobacco use.

Although trade and commerce have existed for millennia, the business corporation is a relatively recent invention. It has only been in existence for 400 years, and the modern corporation is less than 150 years old. ${ }^{9}$ Other time tested commercial models are partnerships, ${ }^{9}{ }^{15} 16$ sole proprietorships, ${ }^{16}$ publicly owned enterprises, ${ }^{25}$ private non-profit enterprises, ${ }^{26}$ and cooperatives. ${ }^{27}$ An intriguing new model, the "community interest company", has recently been developed in the UK. ${ }^{28}$

In the management of large and complex commercial tasks, publicly owned enterprises, private non-profit enterprises, and cooperatives offer attractive alternatives to business corporations for potentially harmful economic activities. These business forms are no less capable of engaging in large scale enterprise than business corporations. In Canada, for example, energy, education, and health services are predominantly supplied by such institutions and they also compete successfully with for-profit corporations in financial services and consumer goods.

The key difference between these institutions and business corporations is that they are not solely programmed to maximise share value and profits. Cooperatives generally are established to meet the common social and economic needs of their member patrons, as well as the need of the community. They are able to distribute surpluses to member patrons or to other ends including the general welfare of the community. ${ }^{27}$ Publicly owned enterprises are programmed to serve any number of public policy purposes. ${ }^{25}$ Similarly, nonprofit enterprises can be programmed to serve social, environmental, and other goals. ${ }^{27} 29$

Using one of these other business forms to manage the manufacture and distribution of tobacco products would allow societies to manage the tobacco market in ways that do not artificially expand tobacco sales, and do not result in the undermining of public health efforts in relation to smoking. Since these business forms are not necessarily required to maximise share value and profits, they can be designed to provide smokers with cigarettes and mandated also to achieve planned reductions in tobacco use.

\section{AN INSTRUMENTAL CHOICE}

The proposal to shift tobacco supply from profit oriented to public interest oriented institutions may be novel (and even politically ambitious), but it is not a romantic or idealised solution. Governments have frequently intervened to replace business corporations with public bodies when doing so is considered to be in the public interest, especially in health, education, and public utility sectors. Virtually every nation is a "mixed economy" of public and private institutions involved in sectors ranging from resource extraction, manufacturing, consumer retail, health services, financial services, etc. There are some services, like water supply and public transportation, which are supplied by business corporations in some countries and by publicly owned or non-profit institutions in others.

Over the past century, there have been frequent shifts of institutions or sectors from public to private or private to public management and ownership. The very fact that governments move responsibility for the provision of some services and goods between public and private sectors underscores the important role of policy choices in this process. These choices are sometimes made explicitly, through legislation or agreements of purchase and sale, and sometimes tacitly, as when governments choose to maintain the status quo.

The decision to allow tobacco supply to continue with the existing form of tobacco corporation, or to move it to a new form of institution should not, and need not, be an ideological choice, but rather an instrumental one. The rational social choice is to select an institutional form that facilitates, rather than hinders, the achievement of our desired public health outcomes and other social goals. Such an institutional choice could be termed "instrumental" in that the institution would be chosen to achieve an outcome, instead of being chosen to serve or propagate an ideology.

A rational, instrumental approach first requires the abandonment of any pre-conceived ideas about what sort of institution "has to" manufacture tobacco. As described above, many different types of institutions can do the job, but different institutional forms have different inherent constraints and opportunities.

One such instrumental approach was suggested by Borland. ${ }^{4}$ His regulated market model (RMM) is intended to reduce smoking and the harms associated with smoking, while respecting the free enterprise system and the likelihood of continuing demand for cigarettes. The instrument chosen is a non-profit Tobacco Products Agency (TPA) monopsony independent of government to manage the supply of cigarettes in ways that remove promotions and provide incentives for cigarette manufacturers to develop less harmful products.

We suggest that it is feasible to set a bolder health objective: the phasing out of tobacco use or its reduction to levels of minimal use, such as those in Europe in the 17th to 19th centuries. Because the profit drive of business corporations would give them an incentive to undermine systems put in place to achieve that goal for reasons we have just discussed, it would be necessary to transfer responsibility for cigarette manufacture and supply away from that sector. One way of doing this would be to acquire their operations through voluntary or legislated purchase. The responsibility for manufacturing and supplying tobacco could then be transferred to an enterprise with the mandate to achieve a timetabled reduction in tobacco and the market power to innovate measures to meet these targets. The preferred structure of this health mandated enterprise (that is, private or public) is a further instrumental choice that may best be made to meet national circumstances and needs. 
Table 1 Comparison of instrumental choices to manage tobacco supply

\begin{tabular}{|c|c|c|c|}
\hline & FCTC style "comprehensive strategy" & Regulated market model ${ }^{4}$ & Non-profit pro-health monopoly model \\
\hline Market instrument & $\begin{array}{l}\text { Depending on country: multinational } \\
\text { corporations; domestic tobacco companies; } \\
\text { state monopolies (with no health mandate) }\end{array}$ & $\begin{array}{l}\text { Existing tobacco manufacturers; } \\
\text { non-profit distribution agency }\end{array}$ & Non-profit tobacco company \\
\hline Health goal & $\begin{array}{l}\text { Reduce mortality and morbidity associated } \\
\text { with tobacco }\end{array}$ & $\begin{array}{l}\text { Reduce mortality and morbidity } \\
\text { associated with tobacco }\end{array}$ & $\begin{array}{l}\text { Eliminate mortality and morbidity associated with } \\
\text { tobacco }\end{array}$ \\
\hline Policy goal & $\begin{array}{l}\text { Reduce the demand for cigarettes; protect } \\
\text { public from second hand smoke; maintain } \\
\text { sustainable legal/regulated market }\end{array}$ & $\begin{array}{l}\text { Reduce demand for cigarettes; reduce } \\
\text { harm for continuing smokers }\end{array}$ & End tobacco use \\
\hline $\begin{array}{l}\text { Strategies } \\
\text { employed }\end{array}$ & $\begin{array}{l}\text { Regulated conditions on the sale of } \\
\text { tobacco product (restrictions on advertising, } \\
\text { mandatory health warnings); higher } \\
\text { prices through taxation; health promotion; } \\
\text { bans on smoking in indoor work and } \\
\text { public places; curbs on smuggling }\end{array}$ & $\begin{array}{l}\text { Continued FCTC style comprehensive } \\
\text { strategy; publicly owned monopsony } \\
\text { with purchaser influence over for-profit } \\
\text { cigarette design and direct control over } \\
\text { distribution; development of less harmful } \\
\text { forms of tobacco products }\end{array}$ & $\begin{array}{l}\text { Continued FCTC style comprehensive strategy as } \\
\text { appropriate; public control over complete tobacco } \\
\text { supply chain; integration of cigarette design, } \\
\text { manufacture and supply with programmes and } \\
\text { policies to reduce smoking }\end{array}$ \\
\hline $\begin{array}{l}\text { Assumptions } \\
\text { (stated and } \\
\text { unstated) }\end{array}$ & $\begin{array}{l}\text { It is not feasible or practicable to end } \\
\text { tobacco use; supply-side approaches } \\
\text { should not be used; tobacco companies } \\
\text { do not have a legitimate role in the } \\
\text { development of public health strategies } \\
\text { to reduce smoking }\end{array}$ & $\begin{array}{l}\text { Better controls will not eliminate tobacco } \\
\text { use-there will be a continuing demand } \\
\text { for tobacco products; World Trade } \\
\text { Organization will not allow tobacco } \\
\text { monopolies; direct control over marketing } \\
\text { of cigarettes will create incentives on } \\
\text { tobacco companies to produce harm } \\
\text { reducing products; there is worthwhile } \\
\text { public health benefit from harm reduced } \\
\text { products }\end{array}$ & $\begin{array}{l}\text { It is possible to end tobacco use once there is no } \\
\text { financial interest in maintaining it; tobacco } \\
\text { companies will continue to undermine tobacco } \\
\text { control measures and will sustain smoking; trade } \\
\text { agreements do not prohibit establishment of } \\
\text { monopolies if doing so achieves justifiable health } \\
\text { objectives and if compensation is provided; } \\
\text { acquiring tobacco supply increases capacity to } \\
\text { innovate to achieve public health goals }\end{array}$ \\
\hline Analogous to & Consumer protection regulations & $\begin{array}{l}\text { Milk marketing boards, Scandinavian } \\
\text { alcohol monopolies }\end{array}$ & Public water systems, post offices \\
\hline $\begin{array}{l}\text { Cigarette } \\
\text { enterprises } \\
\text { motivated to }\end{array}$ & $\begin{array}{l}\text { Maximise profits within a regulated } \\
\text { market }\end{array}$ & $\begin{array}{l}\text { Maximise profits by developing least } \\
\text { harmful cigarettes (according to criteria } \\
\text { sets by monopsony distributor) }\end{array}$ & $\begin{array}{l}\text { Help smokers quit as quickly as possible and } \\
\text { prevent tobacco uptake }\end{array}$ \\
\hline $\begin{array}{l}\text { Enterprise } \\
\text { employees directed } \\
\text { to }\end{array}$ & $\begin{array}{l}\text { Increase profits for tobacco company } \\
\text { or retail owners }\end{array}$ & $\begin{array}{l}\text { Increase profits for tobacco company } \\
\text { or retail owners }\end{array}$ & $\begin{array}{l}\text { Help smokers quit as quickly as possible and } \\
\text { prevent tobacco uptake }\end{array}$ \\
\hline $\begin{array}{l}\text { Relationship } \\
\text { between enterprise } \\
\text { and health authorities }\end{array}$ & Antagonistic & Cooperative & Integrated and collaborative \\
\hline Products sold & $\begin{array}{l}\text { Branded tobacco products (other } \\
\text { products that deliver nicotine are } \\
\text { regulated under different authorities) }\end{array}$ & $\begin{array}{l}\text { Unbranded or less branded tobacco } \\
\text { products and less harmful tobacco } \\
\text { products }\end{array}$ & $\begin{array}{l}\text { Tobacco products progressively designed, } \\
\text { manufactured, packaged and delivered in ways } \\
\text { that facilitate quitting and discourage uptake }\end{array}$ \\
\hline $\begin{array}{l}\text { Direct public } \\
\text { interest control over }\end{array}$ & & $\begin{array}{l}\text { Distribution, promotion, packaging, } \\
\text { pricing }\end{array}$ & $\begin{array}{l}\text { Distribution, promotion, packaging, pricing, } \\
\text { product design, retailing }\end{array}$ \\
\hline $\begin{array}{l}\text { Indirect public } \\
\text { interest control over }\end{array}$ & $\begin{array}{l}\text { Promotion, packaging, pricing, product } \\
\text { design }\end{array}$ & $\begin{array}{l}\text { Product design and manufacture, } \\
\text { retailing }\end{array}$ & \\
\hline
\end{tabular}

Instruments similar to the RMM and our proposed nonprofit model currently exist in France (which maintains a government monopoly in cigarette distribution and limits cigarette sales to licensed retailers, "les buralistes") $)^{30}$ and China (whose tobacco monopoly is the world's largest cigarette manufacturer). ${ }^{31}$ These instruments have not been directed towards public health goals. Their failure to reduce or eliminate tobacco use reflects the fact that they were not instrumentally chosen to achieve these ends, not that they were incapable of doing so. The existence of such distribution and manufacturing agencies, and their greater presence in recent history, underscores that the selection of tobacco supplier is very much a public policy decision.

\section{MAKING THE TRANSITION}

Transforming the tobacco market from one supplied by forprofit corporations to one supplied by public interest institutions could be managed without immediate inconvenience to smokers, tobacco growers, tobacco manufacturer employees, retailers or other market stakeholders, much as private sector transfers in ownership do not necessarily affect those stakeholders. It could be self financing, accessing the tobacco taxes that are currently provided by smokers and allocating them to a tobacco control regimen more clearly directed to meet their needs.

The tobacco market can be transferred to public interest management without losing the necessary equilibrium between the products acceptable to addicted smokers and those provided in the market. Losing this balance could result in smuggling. In the short run, cigarettes sufficiently similar to those currently on the market could continue to be manufactured and supplied through existing channels, so that smokers do not feel a need or desire to switch to illegal or smuggled cigarettes. In the medium run, cigarettes can be redesigned, remarketed, and distributed in ways that facilitate quitting or switching to less harmful nicotine sources. In the long run, aging and successful quitting will result in smokers being a small special population of drug users.

This model similarly respects the needs of those currently engaged in the supply of cigarettes. Those who work for tobacco corporations, who grow tobacco, or who sell cigarettes could continue to do so, although they would immediately be working towards very different goals. To the extent that reductions in smoking result in these jobs 
disappearing at rates faster than natural attrition, transition programmes can be developed, as appropriate.

Existing tobacco corporations could be purchased at fair market value from current shareholders, and the purchase could be financed by industry assets and future revenue streams. Cigarette tax revenues could deliberately be sustained for the transition period to make the initial policy decision more acceptable to government and to taxpayers. Tax revenue levels could be structured in such a way that they decline over time with the decline in the consumption of cigarettes, and leave no incentive for government to perpetuate cigarette sales. Such a system may eventually replace tobacco taxes with a better system of incentives and disincentives to smokers. Methadone strategies, for example, do not use price as a disincentive to use.

Legislation would be required to set the mandate of the new for-health tobacco enterprise. This legislation would likely restrict manufacture and/or wholesale distribution of tobacco products to the public interest licensee and clarify elements of the legal structure of the new organisation. It could also include measures to compensate tobacco victims and limit the liability of the new organisation and its directors and employees for previous wrongs committed. Statutory performance targets (such as targets for reductions in overall tobacco use, or youth smoking levels) could be established, with appropriate governance mechanisms to ensure that the goals are met. The decisions on ownership and accountability of this health mandated tobacco company, as well as transfers in ownership, could be informed by experiences with other public and non-profit enterprise, such as water utilities, public broadcasters, hospital systems, educational institutions, etc. These important matters require further detailed study.

In theory, statutory requirements to phase out smoking could be imposed on existing for-profit tobacco companies, but, for reasons we have outlined above, these companies would be compelled by their obligations to their owners to find ways of appearing to meet the targets (at least enough to avoid being penalised) while ensuring the sustainability of tobacco sales.

\section{NOT DREAMING IN TECHNICOLOR, JUST ENVISIONING A BETTER GOAL}

Mandating enterprises that supply tobacco to assist public health would allow tobacco control regimens to include many measures that are currently considered impossible to implement. A non-profit tobacco manufacturer (either a government or an independent agency) which is obliged by law to meet a targeted reduction in tobacco use would likely voluntarily place their cigarettes in plain packaging, end all forms of promotion, and take steps to ensure that no new smokers entered the market. They would also be able to tap into the knowledge and expertise of their staff to de-market smoking and to design and manufacture their cigarettes in ways that reduce their attractiveness or addictiveness. Economic incentives that currently increase tobacco use could be transformed into incentives to decrease tobacco use. Retailers, for example, are now rewarded for the number of cigarettes they sell, but a public interest tobacco enterprise could instead offer incentives that encourage retailers to recruit their customers into cessation programmes and then replace these retailers with a distribution system more appropriate to addiction treatment. Most importantly, the whole system would work to accelerate, not retard, the work of governments and health agencies.

\section{CONCLUSION}

The public health goal of reducing tobacco use is, now and for the foreseeable future, in direct conflict with tobacco

\section{What this paper adds}

The currently recommended public health approach to tobacco control is to adopt the comprehensive measures included in the Framework Convention on Tobacco Control. These interventions have been found to be effective at reducing the demand for tobacco products. Supply-side measures to reduce tobacco use, with the exception of smuggling controls, are not currently in favour with international authorities.

This paper expands recent proposals for a regulated market model to manage the distribution of cigarettes by proposing that the tobacco market be transformed from one controlled by for-profit business corporations that have a mandate to sell more cigarettes to one managed by other business forms that can have a mandate to promote public health.

corporations' mandate to increase profits. That is why we cannot expect business corporations that profit from the sale of tobacco products to genuinely work to reduce smoking rates, the uptake of smoking by non-smokers, and the addictiveness of their products. Their assistance in achieving public health goals cannot and will not happen with the forprofit corporation's current internal structure and external environment.

A public interest tobacco manufacturer can be established with structures that enable and compel it to reduce tobacco use. There are many forms and hundreds of examples of publicly and privately controlled enterprises that can serve as models for a new non-profit tobacco manufacturer that has a legally binding health mandate. Business corporations in their current form and context are incapable of taking such a direction.

In trying to hold tobacco corporations morally, ethically, or legally responsible for the harms caused by tobacco, we wrongly expect corporations to behave in ways that go against their fiduciary responsibilities. We also ignore the moral, ethical, and legal responsibilities of those who grant business corporations control over the tobacco market when healthier options are available.

The decision to put tobacco in the hands of business corporations was made through government, and can be changed through government. The choice between keeping corporations in tobacco manufacture or replacing them with something else is ours to make.

\section{ACKNOWLEDGEMENTS}

This paper is part of a research project funded by the Canadian Tobacco Control Research Initiative.

\section{Authors' affiliations \\ C Callard, N Collishaw, Physicians for a Smoke-Free Canada, Ottawa, Ontario, Canada \\ D Thompson, Aurora Institute, Vancouver, BC, Canada \\ Competing interests: none declared}

Correspondence to: Cynthia Callard, Physicians for a Smoke-Free Canada, 1226A Wellington Street, Ottawa, Ontario K1Y 3A1, Canada; ccallard@smoke-free.ca

Received 31 January 2005

Accepted 23 March 2005

\section{REFERENCES}

1 World Health Organization. Building blocks for tobacco control: a handbook. Geneva: WHO, 2004. 
2 World Bank. Curbing the epidemic. Governments and the economics of tobacco control. Washington DC: World Bank, 1999.

3 World Health Organization. Framework Convention on Tobacco Control, World Health Assembly Resolution 56.1, 2003.

4 Borland R. A strategy for controlling the marketing of tobacco products: a regulated market model. Tobacco Control 2003;12:374-82.

5 Anon. How do you sleep at night, Mr. Blair? Lancet 2003;362:1865.

6 Gerace TA. The toxic-tobacco law: 'appropriate remedial action'. J Public Health Policy 1999:20:394-407.

7 Government of Alberta. Prevention of youth tobacco use act. Revised Statutes of Alberta, c.p-22. Edmonton, Queen's Printer, 2000.

8 Bates C. What is the future for the tobacco industry? Tobacco Control 2000;9:237-8.

9 Bakan J. The corporation: the pathological pursuit of profit and power. Toronto: Viking Canada, 2004

10 Hammond R. Consolidation in the tobacco industry. Tobacco Control 1998;7:426-8.

11 Cohen J, Milio M, Rozier RG, et al. Political ideology and tobacco control. Tobacco Control 2000;9:263-7.

12 United States Department of Justice. United States of America v. Philip Morris Inc., et al. First Amended Complaint for Damages and Injunctive and Declaratory Relief. Civil Action No. 99-C V-02496 (GK). United States Department of Justice. Washington, 2001.

13 Ashley MJ, Cohen JE. What the public thinks about the tobacco industry and its products. Tobacco Control 2003;12:396-400.

14 Thrasher JF, Niederdeppe J, Farrelly MC, et al. The impact of anti-tobacco industry prevention messages in tobacco producing regions: evidence from the US Truth campaign. Tobacco Control 2004;13:283-8.

15 Micklethwait J, Wooldridge A. The company: a short history of a revolutionary idea. New York: Modern Library, 2003.

16 VanDuzer JA. The law of partnerships and corporations. Toronto: Irwin Law, 2003.

17 Hinkley RC. How corporate law inhibits social responsibility. The Humanist 2002;62(2).
18 Royal Canadian Mounted Police, Information to obtain a search warrant Record 500 26-032904-041. Royal Canadian Mounted Police, Montreal, 2004.

19 Strobel LP. Reckless homicide? Ford's Pinto trial. South Bend, Indiana: And Books, 1980

20 Mokhiber R, Weissman R. The Ten Worst Corporations of 2004. Multinational Monitor Dec, 2004.

21 Friedman $M$. The social responsibility of business is to increase its profits. The New York Times Magazine Sep 13, 1970.

22 Hirschhorn N. Corporate social responsibility and the tobacco industry: hope or hype? Tobacco Control 2004; 13:447-53.

23 Crook $\mathrm{C}$. The good company. A survey of corporate social responsibility. The Economist 2005;374:8410.

24 Liberman J. Where to for tobacco regulation: time for new approaches. Drug and Alcohol Review 2003;22:461-9.

25 HM Treasury Great Britain. Public expenditure statistical analyses 2002-03. London: Stationery Office, 2002.

26 United Kingdom Department of Trade and Industry. Social enterprise: a strategy for success. London: UK Department of Trade and Industry, 2002.

27 Government of Canada. Canadian cooperatives act 1998. Consolidated statutes and regulations. Ottawa: Department of Justice, 2004.

28 United Kingdom Department of Trade and Industry. An introduction to community interest companies. London: UK Department of Trade and Industry, 2004.

29 Statistics Canada. Cornerstones of community: highlights of the national survey of nonprofit and voluntary organizations. Ottawa: Statistics Canada, 2004.

30 La douane. Les débits de tabac, http://www.douane.gouv.fr/ finc. asp?page $=$ organisation/debtab.htm\&cusnum = 810/ (Accessed Mar 7 , 2005).

31 Jiancheng Z, Tao W. China's tobacco industry: a value-chain analysis. Tobacco Journal International 2004;2:101-3.

32 Petro-Canada. Our history, http://www.petro-canada.ca/eng/media/ 10303.htm (Accessed Jan 30, 2005.).

\section{The Lighter Side}

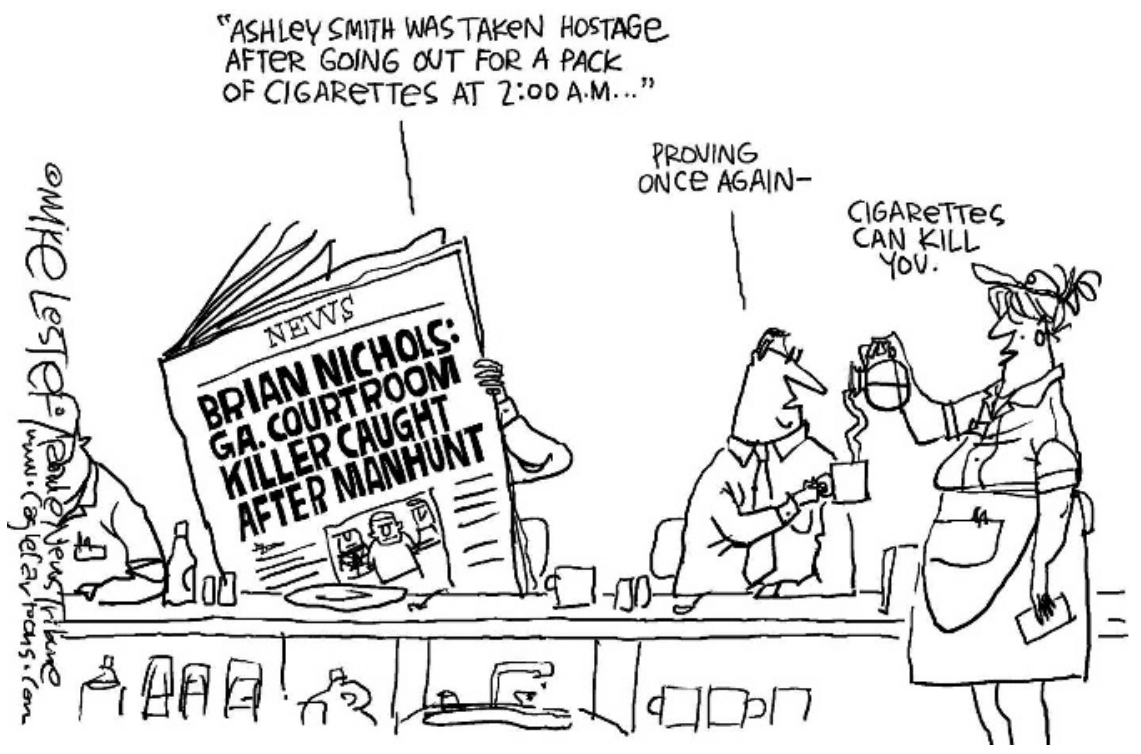

(C) Mike Lester. Rome News Tribune, wwwcaglecartoons.com. 